\title{
Herpes simplex virus type 1 is the leading cause of genital herpes in New Brunswick
}

\author{
Richard Garceau $\mathrm{MD}^{1}$, Danielle Leblanc $\mathrm{RT}^{1}$, Louise Thibault $\mathrm{MD}^{1}$, Gabriel Girouard $\mathrm{MD}^{1}$, Manon Mallet $\mathrm{PhD}^{2}$
}

R Garceau, D Leblanc, L Thibault, G Girouard, M Mallet. Herpes simplex virus type 1 is the leading cause of genital herpes in New Brunswick. Can J Infect Dis Med Microbiol 2012;23(1):15-18.

INTRODUCTION: Little is known about the role of herpes simplex virus (HSV) type 1 (HSV1) in the epidemiology of genital herpes in Canada. Data on herpes viral cultures for two consecutive years obtained from L'Hôpital Dr GL Dumont, which performs all the viral culture testing in New Brunswick, were reviewed. It was hypothesized that HSV1 was the main cause of genital herpes in New Brunswick.

METHODS: Samples of genital origin sent to the laboratory for HSV culture testing between July 2006 and June 2008 were analyzed. Samples from an unspecified or a nongenital source were excluded from analysis. Multiple positive samples collected from the same patient were pooled into a single sample.

RESULTS: HSV was isolated from 764 different patients. HSV1 was isolated in $62.6 \%$ of patients (male, $55 \%$; female, $63.8 \%$ ). HSV1 was isolated in $73.2 \%$ of patients 10 to 39 years of age and in $32 \%$ of patients $\geq 40$ years of age. The difference in rates of HSV1 infection between the 10 to 39 years of age group and the $\geq 40$ years of age group was statistically significant $\left(\mathrm{P}<0.001\left[\chi^{2}\right]\right)$. In a similar Canadian study performed in Nova Scotia, HSV1 was recovered in $53.7 \%$ of positive cultures (male, 36.7\%; female, 58.1\%). The rates of HSV1 infection reported by this study and the present study were significantly different ( $P<0.001\left[\chi^{2}\right]$ for male, $\mathrm{P}=0.012$ for female).

CONCLUSION: In New Brunswick, HSV1 is the dominant type of HSV isolated in samples collected from a genital site. Significant rate differences were demonstrated between the groups 10 to 39 years of age and $\geq 40$ years of age.

Key Words: Canada; Genital herpes; Herpes simplex virus type 1

Lerpes simplex virus (HSV) type 2 (HSV2) is the leading cause of 1 genital ulcers worldwide (1), but either HSV type 1 (HSV1) or HSV2 may be the cause (2). The relative role of HSV1 in herpes simplex genital infections varies from $3.9 \%$ to $78 \%(3,4)$. Most studies have relied on herpes simplex type-specific serology in estimating the significance of HSV2 in causing sexually transmitted infections. However, HSV1 is commonly acquired as an orolabial infection, so antibodies against it cannot be conclusively linked to genital infections. Using methods such as viral culture or molecular assays, it is possible to ascertain the role of HSV1 in causing genital ulcers. In our experience, many samples of genital origin tested in our laboratory grew HSV1. Given that our laboratory has tested all samples from New Brunswick for HSV since 2006 and given the sparsity of Canadian data, we decided to analyze two years of sample results (July 2006 to June 2008), hypothesizing that HSV1 would be the dominant type of HSV identified in those samples.

\section{METHODS}

There are no privately operated laboratories in New Brunswick. L'Hôpital Dr GL Dumont, located in southeast New Brunswick, is the only viral testing laboratory in the province, and has provided HSV

\section{L'herpès simplex de type 1 est la principale cause d'herpès génital au Nouveau-Brunswick}

INTRODUCTION : On ne sait pas grand-chose du rôle du virus de l'herpès simplex de type 1 (VHS1) dans l'épidémiologie de l'herpès génital au Canada. Les chercheurs ont analysé les données des cultures d'herpès viral obtenues pendant deux années consécutives à L'Hôpital Dr-GeorgesL.-Dumont, où toutes les cultures virales sont effectuées au NouveauBrunswick. Ils ont postulé que le VHS1 était la principale cause d'herpès génital dans la province.

MÉTHODOLOGIE : Les chercheurs ont analysé les prélèvements génitaux envoyés en laboratoire entre juillet 2006 et juin 2008, en vue de cultures du virus d'herpès simplex (VHS). Ils ont exclu de l'analyse les prélèvements tirés d'une source non précisée ou d'origine non génitale. Ils ont regroupé dans un seul échantillon les multiples échantillons positifs prélevés chez le même patient.

RÉSULTATS : Le VHS a été isolé chez 764 patients, et le VHS1, chez $62,6 \%$ des patients ( $55 \%$ chez les hommes, et $63,8 \%$ chez les femmes), soit 73,2\% des patients de dix à 39 ans et $32 \%$ des patients de 40 ans et plus. La différence de taux d'infection par le VHS1 entre le groupe des dix à 39 ans et celui des 40 ans et plus était statistiquement significative $\left(\chi^{2}\right.$, $\mathrm{P}<0,001)$. Dans une étude canadienne similaire menée en NouvelleÉcosse, 53,7\% des cultures positives contenaient le VHS1 (36,7\% chez les hommes, $58,1 \%$ chez les femmes). Le taux d'infection par le VHS1 déclaré dans cette étude et celui de la présente étude différaient de manière significative $\left(\chi^{2}, \mathrm{P}<0,001\right.$ chez les hommes, $\mathrm{P}=0,012$ chez les femmes). CONCLUSION : Au Nouveau-Brunswick, le VHS1 est le principal type de VHS isolé dans des échantillons d'origine génitale. On a établi des différences de taux significatives entre le groupe des dix à 39 ans et celui des 40 ans et plus.

${ }^{1}$ Laboratoire de microbiologie, Hôpital Dr GL Dumont; ${ }^{2}$ Pêches et Océans Canada, Moncton, New Brunswick

Correspondence and reprints: Dr Richard Garceau, Laboratoire de microbiologie, Hôpital Dr GL Dumont, 330 avenue Université, Moncton,

New Brunswick E1C 2Z3. Telephone 506-862-4140, fax 506-862-4827, e-mail richard.garceau@vitalitenb.ca 
TABLE 1

Distribution of herpes simplex virus (HSV) type 1 (HSV1) and type 2 (HSV2) in samples collected from genital lesions for viral culture testing, according to age group and sex in New Brunswick between July 2006 and June 2008

\begin{tabular}{|c|c|c|c|c|c|c|c|c|c|c|c|}
\hline & \multicolumn{10}{|c|}{ Age group, years } & \multirow[b]{2}{*}{ Total } \\
\hline & $10-14$ & 15-19 & $20-24$ & $25-29$ & $30-39$ & $40-49$ & $50-59$ & $60-69$ & $70-79$ & $>80$ & \\
\hline \multicolumn{12}{|l|}{ Women } \\
\hline HSV1, n & 6 & 99 & 123 & 73 & 74 & 25 & 20 & 5 & 2 & 0 & 427 \\
\hline HSV2, n & 0 & 24 & 36 & 33 & 40 & 45 & 34 & 12 & 14 & 4 & 242 \\
\hline Total, n & 6 & 123 & 159 & 106 & 114 & 70 & 54 & 17 & 16 & 4 & 669 \\
\hline HSV1/HSV1+HSV2, \% & 100 & 80.5 & 77.4 & 68.9 & 64.9 & 35.7 & 37 & 29.4 & 12.5 & 0 & 63.8 \\
\hline \multicolumn{12}{|l|}{ Men } \\
\hline HSV1, n & 0 & 8 & 26 & 15 & 13 & 9 & 2 & 1 & 0 & 0 & 74 \\
\hline HSV2, n & 0 & 2 & 10 & 3 & 14 & 13 & 11 & 5 & 3 & 0 & 61 \\
\hline Total & 0 & 10 & 36 & 18 & 27 & 22 & 13 & 6 & 3 & 0 & 135 \\
\hline HSV1/HSV1+HSV2, \% & 0 & 80 & 72.2 & 83.3 & 48.1 & 40.9 & 15.4 & 16.7 & 0 & 0 & 54.8 \\
\hline
\end{tabular}

the Copan UTM 3 mL kit (Copan Diagnostics, Inc, USA). Samples were then stored and shipped at $-70^{\circ} \mathrm{C}$.

Samples submitted in the wrong transport medium, at room temperature or without sufficient identifiers were not processed and were excluded from the study.

The inoculation of processed samples was performed using flatbottom 96-well microplates, with each sample being inoculated in two wells of each of the following four cell lines: A549, MRC-5, Mink and Vero. The microplates were then centrifuged at $1600 \mathrm{rpm}$ for $60 \mathrm{~min}$ at $33^{\circ} \mathrm{C}$, after which they were incubated at $35^{\circ} \mathrm{C}$ in $5 \% \mathrm{CO}_{2}$ for 10 days. The microplates were inspected daily for cytopathic effect (CPE) using an inverted microscope.

The supernatant of wells showing CPE affecting at least $75 \%$ of the cells were harvested for subsequent passage in a vial containing the same cell line. Cells harvested from an infected well were deposited on a 10-well slide for staining with type-specific HSV monoclonal immunofluorescent antibodies (MFA) (Thermo Fisher Scientific, USA). Only samples displaying a typical CPE and typed by MFA were reported as positive for HSV1 or HSV2. Samples with CPE typical of a herpes virus that could not be typed as HSV1 or HSV2 were then further tested for cytomegalovirus or varicella zoster virus by MFA. Samples with a typical or an atypical CPE that could not be typed with the regular set of MFA were not retested with a different set of MFA or by a molecular method. Cultures without CPE after 10 days were reported as negative.

Results from all samples submitted for HSV culture from July 2006 to June 2008 were studied. Results from samples that had grown HSV1 or HSV2 were retrieved and inspected by one of the authors (DL). Results from genital site samples that had grown either HSV1 or HSV2 from patients older than nine years of age were included in the present study.

\section{RESULTS}

Between July 2006 and June 2008, 4263 sample results were included for analysis. HSV had been isolated in 1304 samples, from which 805 genital samples from 764 patients were positive for HSV. No samples were infected by both HSV1 and HSV2, either in samples collected from a single date or multiple dates. The available data did not allow determination of the number of rejected samples, samples with an atypical $\mathrm{CPE}$ or with an isolate that could not be typed. No sample negative for HSV by viral culture was retested by a molecular assay.

HSV1 was identified in $62.6 \%$ of all positive patients and was more frequent in females $(63.8 \%)$ than in males (55\%) (Table 1). Among patients with a positive genital sample, female patients were overrepresented (635 female patients, 129 male patients), but the difference in the HSV1 discovery rates between male and female patients was not significant. No significant regional differences were seen in the rate of HSV1/HSV2 genital infections.

In comparison, in the $\geq 40$ years of age group, the rate of occurrence of HSV1 dropped significantly. The difference in the rates of occurrence of HSV1 between the combined population of males and females for the age groups 10 to 39 years $(77 \%)$ and $\geq 40$ years $(32 \%)$ was statistically significant $\left(\mathrm{P}<0.001\left[\chi^{2}\right]\right)$.

\section{DISCUSSION}

In 1992, our laboratory started providing HSV viral culture services, and from our observations we suspected that HSV1 was the dominant strain of HSV from samples of genital origin. Until recently, we were unable to prove this observation; however, since the spring of 2006 we have processed viral cultures from all New Brunswick hospitals and now have gathered enough data to confirm this hypothesis. A detailed review of the number and type of samples received since June 2006 make us confident that we have gathered all samples collected for HSV detection in New Brunswick. Double counting was ruled out because all positive samples collected in duplicate from a single patient were reviewed by one of the authors (RG) and counted as a single sample.

Viral culture was used as a surrogate for incident infection. We were unable to determine if the isolated HSV was from a primary or a recurrent episode. The present study may have underestimated the role of HSV1 in episodes of genital herpes because the median recurrence rate for patients with HSV2 is much greater than that for patients with HSV1 infection (6). On the other hand, there is a marked predominance of HSV1 isolates in patients presenting to their primary care provider with a first, symptomatic genital herpes infection (7). How these two observations affect our results is difficult to estimate.

HSV1 is the main cause of genital herpetic lesions in New Brunswick, for both men and women, and predominantly affects patients $<40$ years of age. This observation confirms the results of a Canadian study by Foward and Lee (8) concluded eight years ago in Nova Scotia. The age groups differ slightly because the study by Forward and Lee included patients $\geq 16$ years of age; however, the number of patients in our cohort of nine to 15 years of age was negligible (six patients). Women constituted the bulk of the cases in our cohort, accounting for $83.2 \%$ of all cases of genital herpes. The cohort of women 15 to 39 years of age was our largest group of patients infected with HSV1 (55.1\%). This was also the case in the study by Forward and Lee (79.3\%). The lower rate of HSV1 in older patients in our study may represent a lower incidence of HSV1 in this age group due to different sexual practices, but may also reflect the tendancy of HSV1 to reactivate less frequently in comparison with HSV2. We cannot exclude the possibility that patients with recurrent genital herpes may not have presented to their care provider for diagnosis because they were already aware of their condition. This may explain the relatively low number of patients tested for genital herpes in the present study. Older patients infected with genital herpes in the present study may then be primary symptomatic cases, while younger patients may represent recurrent infections.

HSV1 is transmitted through contact with a person who is shedding virus at a peripheral site, a mucosal surface or in genital or oral secretions. Aerosol and fomite spread are unusual means of 
TABLE 2

Studies on the role of herpes simplex virus type 1 (HSV1) as a cause of genital herpes infection, based on viral culture or nucleic acid test

\begin{tabular}{|c|c|c|c|c|}
\hline Author (reference), year & Period & Country & Population studied & Overall HSV1 proportion, \% \\
\hline \multirow[t]{3}{*}{ Nilsen and Myrnel (19), 2000} & 1987-1989 & Norway & Outpatient clinic & 36.0 \\
\hline & 1992-1995 & & & 66.0 \\
\hline & 1996-1998 & & & 51.0 \\
\hline Löwhagen et al (20), 2000 & 1995-1999 & Sweden & STD clinic & 44.0 \\
\hline \multirow[t]{2}{*}{ Roberts et al (4), 2003} & 1993-2001 & United States & University clinic & 1993: 31.0 \\
\hline & & & & 2001: 78.0 \\
\hline Bruinsten et al (3), 2001 & 1996 & Netherlands & STD clinic & 3.9 \\
\hline Nieuwenhuis et al (21), 2006 & 1996-2001 & Netherlands & STD clinic & 52.0 \\
\hline Manavi et al (22), 2004 & 1998-2001 & Scotland & STD clinic & 54.3 \\
\hline Nilsen et al (23), 2007 & 1999-2001 & Tanzania & STD clinic & 8.6 \\
\hline Theng and Chan (24), 2004 & 2001 & Singapore & STD clinic & 11.6 \\
\hline Zmira et al (25), 2003 & 1993-2002 & Israel & Hospital laboratory & 66.3 \\
\hline Thompson (26), 2000 & 1995-1999 & England & STD clinic & 71.0 \\
\hline Kortekangas-Savolainen and Vourinen (27), & 1994-1996 & Finland & STD clinic & 18.7 \\
\hline 2007 & 2000-2002 & & & 25.9 \\
\hline Janier et al (28), 2006 & 1999-2002 & France & STD clinic & 14.5 \\
\hline Filén et al (29), 2004 & 2001-2002 & Sweden & STD clinic & 72.0 \\
\hline Ramaswamy et al (30), 2004 & 2002 & England & STD clinic & 9.0 \\
\hline Buxbaum et al (31), 2003 & 2003 & Germany & STD clinic & 22.0 \\
\hline Aryee et al (32), 2005 & 2004 & Gambia & STD clinic & 15.0 \\
\hline Hope-Rapp et al (33), 2010 & 1995-2005 & France & STD clinic & 37.0 \\
\hline Pena et al (34), 2010 & 2007 & United States & Private laboratory & 32.0 \\
\hline
\end{tabular}

STD Sexually transmitted disease

transmission (9). Change in sexual practices are often cited, but few studies have examined the sexual repertoire of adults according to age groups. Although oral sex is reported to be frequent in adolescents and young adults, we found only one study reporting the frequency of these practices in older adults (10). This study confirmed that persons practicing fellation and cunnilingus are significantly younger than those who do not practice them.

The present study had several limitations. The samples were submitted with limited clinical data and it was not known if the samples were collected from a primary episode or a recurrence. The detection method used (viral culture), although very specific, is not the most sensitive. The use of a molecular method would have increased the recovery of HSV (11). Whether the use of a molecular method would have altered the ratio of HSV1/HSV2 is unknown.

We compared our data with those presented in Forward and Lee's study (8), after adjusting our age groups. Overall, the rate of occurrence of HSV1 was lower in male patients from Nova Scotia (New Brunswick 55\% versus Nova Scotia 36.7\%, $\mathrm{P}<0.002)$. The rates for female patients were also different (New Brunswick 63.8\% versus Nova Scotia $58.1 \%, \mathrm{P}=0.034$ ). As in the study by Forward and Lee, female patients were over-represented, constituting approximately $80 \%$ of all patients tested for all age groups in both studies.

Although some differences exist, our study confirms Forward and Lee's findings that in Atlantic Canada, HSV1 is the main cause of genital herpes. Based on these two studies, however, HSV1 occurrence rates are lower in Nova Scotia than in New Brunswick.

The study by Forward and Lee (8) and the present study differed in several ways. Forward and Lee's study used a single cell line (A549) kept for seven days in a stationary cell tube. We used four cell lines kept for 10 days, including the Mink lung cell line. The Mink lung cell line is reported to be more sensitive than Vero and MRC-5 for the recovery of HSV in culture (12). We used a spin-amplified microplate cell culture assay that was also reported to increase the recovery of viruses $(13,14)$. Whether differences in culture methods preferentially affected the recovery of HSV1 compared with HSV2 is unknown.

The two studies are separated by eight years, and a change in sexual practices over time cannot be excluded. Fellatio and cunnilingus are reported to be more common in younger age groups (15), being perceived as safer than intercourse and as a means of averting pregnancy (16). Such a change would favour the transmission of HSV1 in this population. Forward and Lee's study and the present study indirectly support this observation. Furthermore, most adolescents have no HSV1 antibodies (17), making them susceptible to a primary genital infection with this organism. Whether the susceptibility to HSV1 primary genital infection has varied over time (eg, 1998 to 2001 versus 2006 to 2008) or location (Nova Scotia versus New Brunswick) is unknown. Access to medical care may have differed between Nova Scotia and New Brunswick, and also during the two study periods.

No other published studies based on direct detection concerning the role of HSV1 in genital herpes in Canada were found, although regional differences were mentioned (18). The relative importance of HSV1 in genital herpes varies considerably in other areas of the world (Table 2). Most published studies include a greater proportion of female patients, similar to the present study. Although not meant to be exhaustive, the review of the published studies in the present report found HSV2 to be the main cause of genital herpes.

\section{CONCLUSION}

In New Brunswick, HSV1 is the dominant type of HSV detected in samples collected from genital sites. Significant rate differences are seen between the 10 to 39 years of age and the $\geq 40$ years of age groups. Our data confirm the findings of a similar study conducted in Nova Scotia (8). We encourage other Canadian laboratories to reassess the role of HSV1 in the etiology of HSV genital lesions.

ACKNOWLEDGEMENTS: The authors thank Mr Steven Mills for reviewing the manuscript.

\section{REFERENCES}

1. Augenbraun MH. Genital skin and mucous membrane lesions. In:

Mandell GL, Bennett JE, Dolin R, eds. Mandell, Douglas and

Bennett's Principles and Practice of Infectious Diseases.

Montréal: Churchill Livingston, 2005:1338-47.

2. Lignes directrices canadiennes pour les MTS édition de 2006.

Agence de la Santé publique du Canada, 2008. 
3. Bruinsten SM, Cairo I, Fennema H et al. Diagnosing genital ulcer disease in a clinic for sexually transmitted diseases in Amsterdam, The Netherlands. J Clin Microbiol 2001;39:601-5.

4. Roberts CM, Pfiser JR, Spear SJ. Increasing proportion of herpes simplex virus type 1 as a cause of genital herpes infection in college students. Sex Transm Dis 2003;30:797-800.

5. Statistics Canada. Population estimates and projections, 2009. $<$ http://www40.statcan.ca/01/cst01/demoa2-eng.htm> (Accessed on February 11, 2010).

6. Benedetti J, Corey L, Ashley RA. Recurrence rates in genital herpes after symptomatic first-episode infection. Ann Intern Med 1994;121:847-54.

7. Nageswaran A, Shen RN, Craig J, Kyi TT, Priestley CJ, Kinghorn GR. A comparison of referral patterns and caracteristics of patients with first episode symptomatic genital HSV-1 and HSV-2 infections in Sheffield. Genitourin Med 1996;72:206-9.

8. Forward KR, Lee SH. Predominance of herpes simplex virus type 1 from patients with genital herpes in Nova Scotia. Can J Infect Dis 2003;14:94-6

9. Corey L. Herpes simplex virus. In: Mandell GL, Bennett JE, Dolin R, eds. Mandell, Douglas and Bennett's Principles and Practice of Infectious Diseases. Montréal: Churchill Livingston, 2005:1762-80.

10. Messiah A, Blin P, Fiche V, ACFS group. Sexual repertoires of heterosexuals: Implications for HIV/sexual transmitted disease risk and prevention. AIDS 1995;9:1357-65.

11. Strick LB, Wald A. Diagnostics for Herpes Simplex Virus: Is PCR the new gold standard? Mol Diag Ther 2006;10:17-28.

12. Zhao LS, Landry ML, Balkovic ES, Hsiung GD. Impact of cell culture sensitivity and virus concentration on rapid detection of herpes simplex virus by cytopathic effects and immunoperoxidase staining. J Clin Microbiol 1987;25:1401-5.

13. Pruneda RC, Almanza I. Centrifugation-shell vial technique for rapid detection of herpes simplex virus cytopapthic effect in Vero cells. J Clin Microbiol 1987;25:423-4.

14. Seno M, Takao S, Fukuda S, Kanamoto Y. Enhanced isolation of influenza virus in conventional plate cell cultures by using lowspeed centrifugation from clinical specimens. Am J Clin Pathol 1991;95:765-8.

15. Gupta R, Warren T, Wald W. Genital herpes. Lancet 2007;370:2127-37.

16. Halpern-Fisher BL, Cornell JL, Kropp RY, Tschann JM. Oral versus vaginal sex among adolescents: Perceptions, attitudes, and behavior. Pediatrics 2005;115:845-51.

17. Shulman JD. Recurrent herpes labialis in US children and youth. Community Dent Oral Epidemiol 2004;32:402-9.

18. Ratnam S, Severini A, Zahariadis G, Petric M, Romanowski B. The diagnosis of genital herpes-beyond culture: An evidence-based guide for the utilization of polymerase chain reaction and herpes simplex virus type-specific serology. Can J Infect Dis Med Microbiol 2007;18:233-40.

19. Nilsen A, Myrnel H. Changing trends in genital herpes simplex infection in Berge, Norway. Acta Obstet Gynecol Scand 2000;79:693-6.
20. Löwhagen GB, Tunbäck P, Andersson K, Johannisson G. First episode of genital herpes clinic in a Swedish STD population: A study of epidemiology and transmission by the use of herpes simplex virus typing and specific serology. Sex Transm Inf 2000;76:179-82.

21. Nieuwenhuis RF, Doornum GJJ, Mulder PGH, Neuman M, van der Meijden WI. Importance of Herpes simplex type 1 (HSV1) in primary genital herpes. Acta Derm Venereol 2006;86:129-34.

22. Manavi K, McMillan A, Ogilvie M. Herpes simplex virus type 1 remains the principal cause of initial anogenital herpes in Edinburgh, Scotland. Sex Transm Dis 2004;31:322-4.

23. Nilsen A, Kasubi MJ, Mohn SC, Mwakagile D, Langeland N, Haarr L. Herpes simplex virus infection and genital ulcer disease among patients with sexually transmitted infections in Dar es Salaam, Tanzania. Acta Derm Venereol 2007;87:355-9.

24. Theng TS, Chan RK. Genital Herpes in a sexually-transmitted infection clinic in Singapore: A 1-year retrospective study. Ann Acad Med Singapore 2004;33:200-3.

25. Zmira S, Scherf E, Dan M. Herpes simplex virus type 1 is the prevailing cause of genital herpes in the Tel Aviv area, Israel. Sex Transm Infect 2003;30:794-6.

26. Thompson C. Genital herpes simplex typing in genitourinary medicine: 1995-1999. Int J STD AIDS 2000;11:501-2.

27. Kortekangas-Savolainen O, Vuorinen T. Trends in Herpes simplex virus type 1 and 2 infections among patients diagnosed with genital herpes infection in a Finnish sexually transmitted disease clinic, 1994-2002. Sexually Transm Dis 2007;34:37-40.

28. Janier M, Scieux C, Méouchi R, et al. Virological, serological and epidemiological study of 255 consecutive cases of genital herpes in a sexually transmitted disease clinic of Paris (France): A prospective study. Int J STD AIDS 2006;7:44-9.

29. Filén F, Strand A, Allard A, Blomberg J, Herrmann B. Duplex realtime polymerase chain reaction assay for detection and quantification of herpes simplex virus type 1 and herpes simplex virus type 2 in genital and cutaneous lesions. Sex Transm Dis 2004;6:331-6.

30. Ramaswamy M, McDonald C, Smith M, et al. Diagnosis of genital herpes by real time PCR in routine clinical practice. Sex Transm Infect 2004;5:406-10.

31. Buxbaum S, Geers M, Gross G, Schöfer H, Rabenau HF, Doerr HW. Epidemiology of herpes simplex virus types 1 and 2 in Germany: What has changed? Med Microbiol Immunol 2003;192:177-81.

32. Aryee EA, Bailey RL, Natividad-Sancho A, Kaye S, Holland MJ. Detection, quantification and genotyping of Herpes simplex virus in cervicovaginal secretions by real-time PCR: A cross sectional survey. Virol J 2005;2:61-71.

33. Hope-Rapp E, Anyfantakis V, Fouéré S, et al. Etiology of genital ulcer disease. A prospective study of 278 cases seen in an STD clinic in Paris. Sex Transm Dis 2010;37:153-8.

34. Pena KC, Adelson ME, Mordechai E, Blaho JA. Genital herpes simplex virus type 1 in women: Detection in cervicovaginal specimens from gynecological practices in the United States. J Clin Microbiol 2010;48:150-3. 


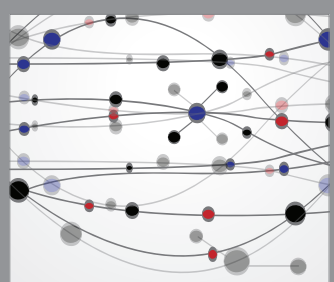

The Scientific World Journal
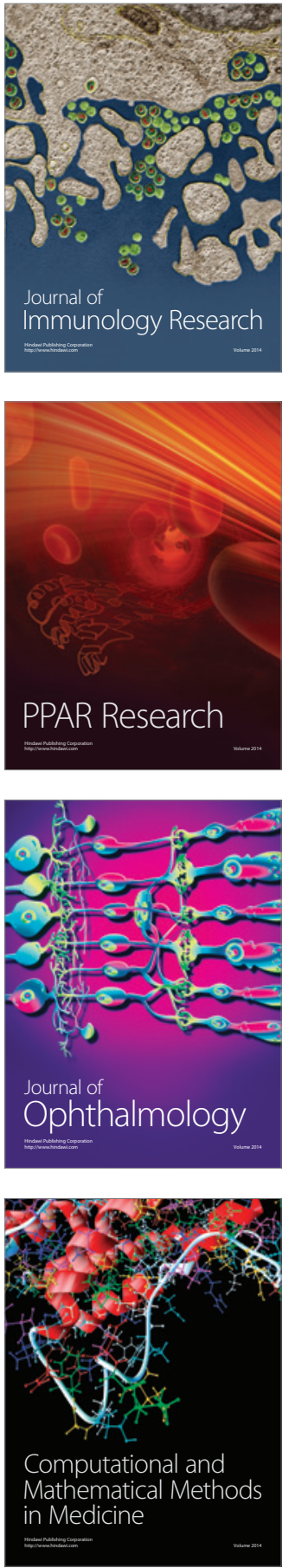

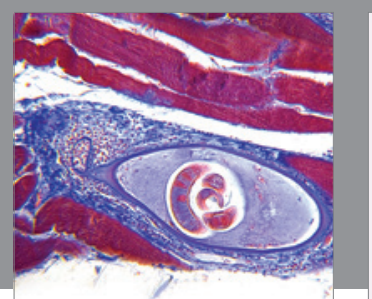

Gastroenterology Research and Practice

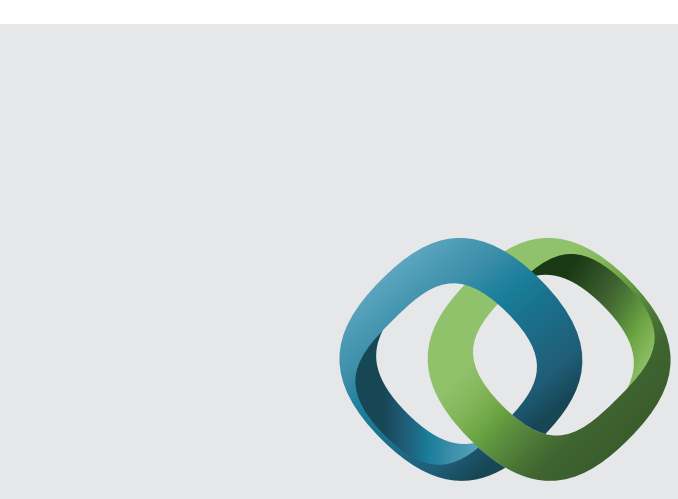

\section{Hindawi}

Submit your manuscripts at

http://www.hindawi.com
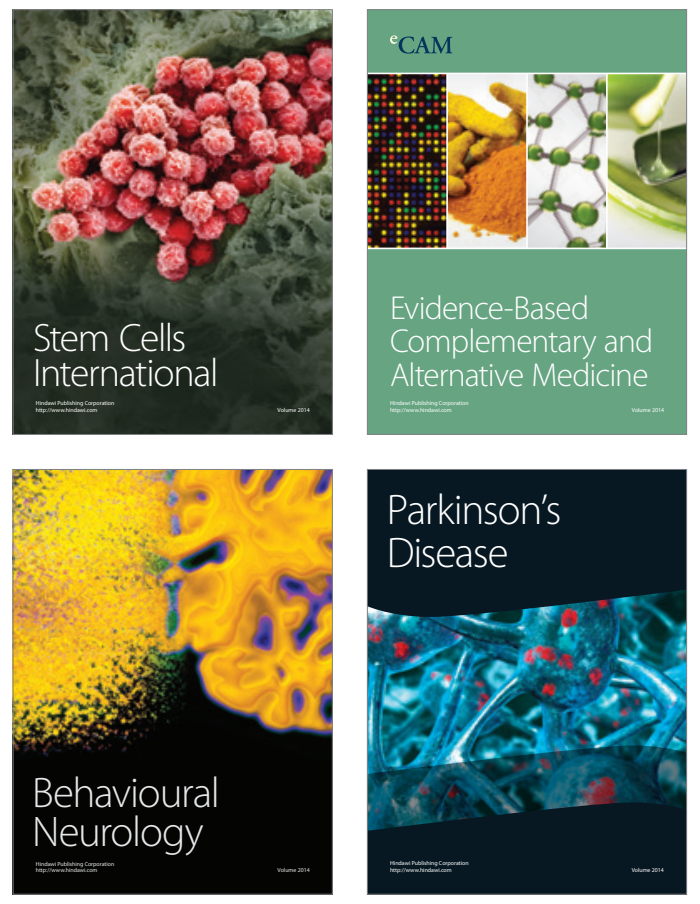
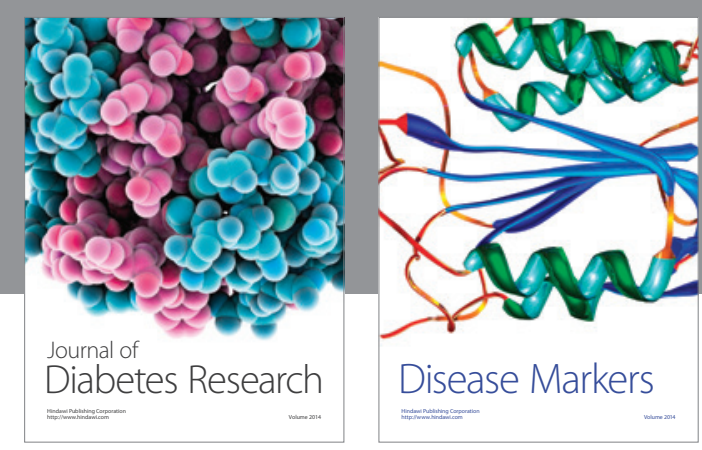

Disease Markers
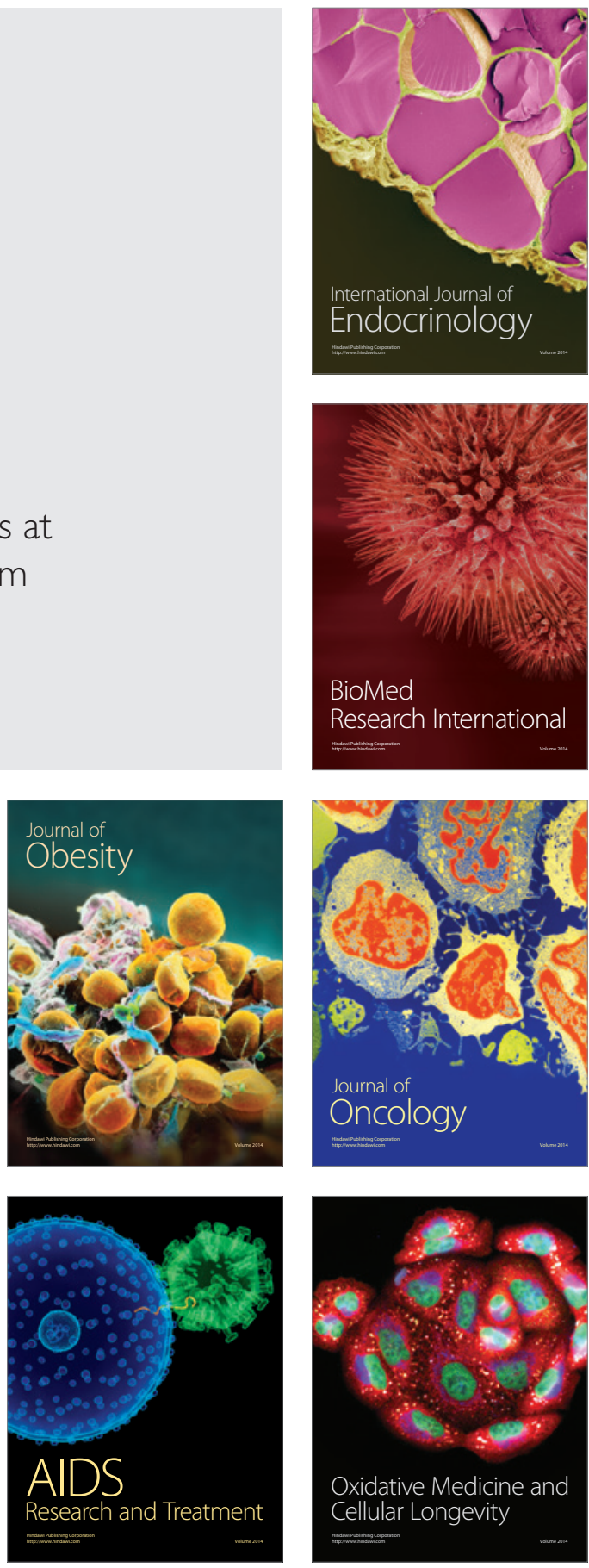